\title{
ПАНОРАМА
}

\section{Ihor Karivets' \\ CONTEMPLATION, MIRACLE AND NOVELTY: TOWARDS THE FOUNDATIONS OF RELIGIOUS EXPERIENCE}

\author{
Motto: \\ It is contemplation that is important for discovering novelty in the lifeworld. \\ Wonder lasts but nine days. \\ English Proverb
}

\begin{abstract}
Introduction
One of the components of the religious experience is a perception of miracle. The concept of a miracle has a long history. Since the times of St. Augustine a miracle has become an object of serious investigations. Such investigations are interdisciplinary, because a miracle belongs to the phenomena, which are analyzed not only by theology, but also by philosophy of religion, religious studies, physics, etc.

However, a miracle is mostly considered in the theological context. In this article I would like to look at a miracle in a wider sense. I stress that a miracle is an aesthetic phenomenon connected with the ability of a human being to perceive the new, the unusual, the unexpected, the unrepeated and astonishing.
\end{abstract}

\section{The Traditional Definitions of a Miracle}

The analysis of a miracle have been done by such researchers as T.M. Drange [Drange, 1998] from the philosophy of science point of view, which tries to understand the meaning of a miracle for science and religion; J. Nickell [Nickell, 1996] from the point of view of «magic thinking» in the culture of New Age, with the focus on Christian artefacts, for example, the Shroud of Turin and «divine experience»; Z. Mikolejko [Mikolejko, 2010] from the point of view of Spinoza and P. Bayle and taking into consideration the classification of miracles by Saint Thomas Aquinas. Thomas Moore's book «The Re-enchantment of Everyday Life»[Moore, 1997] is of great value for rehabilitation of a miracle in daily life. The author emphasizes on the importance of the revival of Neo-Platonism, M. Fichino's mysticism, the mystical mythology of C.G. Jung as the intellectual and aesthetic inspirations for contemporary human beings.

(C) I. Karivets', 2013 
The contemporary American philosopher D. Corner in his book «The Philosophy of Miracles» summed up the existing traditional definitions of a miracle:

1) a miracle as a violation of the laws of nature;

2) a miracle as an event that exceeds the bounds of natural relationships of cause and effect;

3) a miracle as a chance;

4) a miracle as an intervention of the supernatural force (God) [Corner, 2007].

Now I would like to consider classical science and the laws of nature in the context of the traditional definitions of a miracle.

\section{Classical Science, the Laws of Nature and a Miracle}

C.S. Lewis, one of the famous Oxford Christian theologists, understands miracle as «an interference with Nature by supernatural power» [Lewis, 1947: p. 81], but he stressed that this interference does not mean a violation of laws of nature. C.S. Lewis puts: «the divine art of miracle is not an art of suspending the pattern to which events conform but of feeding new events into that pattern» [ibid., p. 81]. A miracle occurs when God «annihilates or creates or deflects a unit of matter» [ibid., p. 81]. C.S. Lewis adds: «We see every day that physical nature is not in the least incommoded by the daily inrush of events from biological nature or from psychological nature. If events ever come from beyond Nature altogether, she will be no more incommoded by them. Be sure she will rush to the point where she is invaded, as the defensive forces rush to a cut in our finger, and there hasten to accommodate the newcomer» [ibid., p. 81]. So we see that C.S. Lewis does not state that religious significance is a necessary condition of a miracle, but he takes an important aspect of the concept of a miracle to be its religious significance, i.e. as a miracle is understood in the Bible [ibid., p. 143ff]. Contemporary theologist R. Swinburne also defines a miracle as «event of an extraordinary kind, brought about by a god, and of religious significance», and understands an event of an extraordinary kind to be «an event which goes against [natural laws] or "violates" them» [Swinburne, 1970: p. 3]. As we can see their definition of a miracle in the general terms coincide with the Hume's definition: «A miracle may be accurately defined as a transgression of a law of nature by a particular volition of the Deity or by the interposition of some invisible agent» [Hume, 1975: p. 115n.].

Classical science assumes that the laws of nature are homogeneous and nothing can violate them, and natural phenomena are linked with one another by rigid relationships of cause and effect, then a miracle is regarded as an anomaly, as «supernatural», something that is beyond the limits of human understanding. A miracle does not violate the laws of nature. It only transcends them proving that they are not «eternal». A miracle indicates that God is neither dogmatic nor fanatic. Laws can be changed but not cancelled, because: «First of all it is necessary to assert that the notion of a miracle as the notion of violation of the natural laws and as something that brings chaos into the world order is deeply wrong. It would be possible to talk about violation of the laws of nature if the fact of a miracle had cancelled some law» [Хмель, 2010: с. 41]. And this can be seen on the example of quantum physics. The laws on the subatomic level are quite different from the ones on the level of physical bodies which consist of the elementary particles. Quite different regularities are combined in one physical body; regularities that seems to contradict each other. 
Classical science considers a miracle as a chance. It does not admit the fact that miracle is a part of reality which cannot be calculated, figured out, conceptualized. Classical science cannot go beyond the limits of understanding's schematism as I. Kant shows in «Critique of Pure Raison». That is the schematism of understanding which rules out the possibility of miracle's presence in lifeworld and in nature. A miracle reveals limitedness of the causality principle and also «the victory of a different principle of determination, and it simply marks the breakdown of outdated ontologies that are too narrow to make room for the unlimited richness of reality» [Bunge, 1959: p. 351]. This is a characteristic of classical science to restrain causality to only one cause, namely natural (naturalism) and to reduce the natural cause to the physical (physicalism). However, even Aristotle distinguished four causes, i.e. material, formal, efficient, and final, which explain how things come into being and change. Moreover, M. Bunge argues: «Novelty is not the insoluble caput mortuum imagined by irrationalism; it is explainable, but with the help of all the categories of determination» [ibid., p. 218]. A human being does not know all the factors which have caused what is called «the new», «the strange».

\section{Etymological Approach to a Miracle}

Our approach to the determination of the miracle's nature can be called etymological and phenomenological, and the one which is focused on human beings and, to be more precise, on the mode of their perception of the world around them and themselves in the world. It is not a miracle itself but its sense that is important for the researcher of a miracle, since there is some force that manifests itself through it. A miracle as a manifestation of some force shows us that our being with all its paradoxes is miraculous.

Let us begin with the etymology of the word «miracle» («divo») in Ukrainian language ${ }^{1}$. If we trace the origin of this word we shall find out that it derives from «divo» in the Primitive Slavonic language and is connected with the Old Indian word «dhi» which means «to contemplate, to observe, to notice». So we can conclude that the word «divo» originally meant «vision, something that has come into sight». Other researchers assume that the word «divo» comes from the same root «di-», that is «to shine, to beam», as in Ukrainian word «den'» («day» in English) and in the Old Indian words «diu» («sky»), «deious» («God» or strictly speaking - «celestial»), and also in Latin words «deus» («God»), «divinus» («of a God») [Етимологічний словник української мови, т. 2, 1985: с. 67]. Thus, a miracle is something unusual, a celestial sign, an omen. A human being looks at the world with wonder for he/she sees there some celestial signs, some omens.

It should be also mentioned that the verb «to look at» («divitisja») in Ukrainian language originally meant «to wonder» («divuvatisja») [ibid., p. 66.]. It is interesting that the Spanish word for «to look at someone» - «mirar» that derived from the Vulgar Latin «mirare» at first meant «to look at something with wonder». So we can suppose that the word for «to look at» in these languages lost its original meaning «to wonder», «to admire». Therefore I think that in the ancient times there was the human being's admiration of all creation reflected in language.

1 The meaning of a miracle in Latin and Greek languages is well known [Encyclopedia Britannica, Vol. 15, 1959: p. 585]. So I decided to explore more deeply the meaning of a miracle in Ukrainian, because it is less known for readers. 


\section{Phenomenological Approach to a Miracle}

There is no place for a miracle in everyday life, because a miracle exists only for those who can see it. A miracle can be seen even in the existence of some laws. Science and everyday life, as it appears to people, deals with something that can be typisized (A. Schütz ) in nature and in the society as well. The laws of nature and the laws of society are based on the recurrence.

As S.A. Soshynskij wrote: «A miracle is the God's call to a human being and it demands from him/her the free acceptance, a motion towards Him» [Сошинский, 2001: c. 95]. A miracle is a proof of freedom, of unconditionalness of occurrences and the whole life, and the possibility of their renewal, whereas science deals with something that is regularly repeated. A miracle cannot be placed within the limits of «everyday consciousness» or «common science» (T. Kun). A miracle brings forth a new sense, it is the sign of the unknown, whereas science and everyday life deal with the known and expend its limits. A miracle cannot be defined as «unnatural», as something that exists outside the natural world - «supernatural». Through a miracle and due to it the absolute and the positive manifest itself; and that is the essence of a miracle. A miracle is defined not from below but from above, and not by what it is not but by what it represents - the Absolute, the God. Otherwise it is just an apparent «miracle», senseless surprise which brings emptiness and destruction. Real miracle is visible in the world. Thus, a miracle is the sense and the sign of transcendent which indicates freedom and unconditioned life. Moreover, a miracle does not mean the cancellation of the laws of nature and intervention of the supernatural forces. On the contrary, a miracle affirms that natural sciences do not know ultimately the laws of nature since they accept the strict determinism. Certainly, the representatives of different confessions consider miracles as the agency of God. But what is important for us that is the ability of a miracle to excite the primitive state of astonishment and to reveal a human being in such way ${ }^{2}$. A miracle meant to motivate a human being for asking questions and breaking stereotypes. The mere fact of the world existence is astonishing. But the world exists in concrete entirety. The ability to perceive the world as such entirety is the beginning of philosophy and the ethical attitude to the world ${ }^{3}$. An entirety cannot be subjected to the ultimate conceptualization and analysis. That is why it also amazes. For what cannot be analyzed and defined is nothing for positive science and analytical philosophy which want to deal only with the observable, i.e. the definite. But even the observable may wonder. This is what J. Krishnamurti says regarding this: "If you observe very closely what is taking place and examine it, you will see that it is based on an intellectual conception, and the intellect is not the whole field of existence; it is a fragment, and a fragment, however cleverly put together, however ancient and traditional, is still a small part of existence whereas we have to deal with the totality of life. And when we look at what is taking place in the world we begin to understand that there is no outer and inner process; there is only one unitary process, it is a whole, total movement,

2 The second sentence points to what Aristotle called «wonder».

3 The Ancient Greeks discovered the ability of a human being to find what forms the basis (Being) that is not hidden any more. Being manifests itself through the Word (Logos). Without the word it remains obscure. This is a miracle that breaks the initial «understanding» inherent to «the Spirit of Epoch». Pharisees demanded that Jesus Christ work a sign in order to demonstrate His authority to teach, but He refused to do it, since a miracle is commonly considered as something extraordinary, unusual, sensational, something that evokes rumours. It does not astonish deeply, as a human being has not independently broken the generally accepted and remained within its limits. 
the inner movement expressing itself as the outer and the outer reacting again on the inner. To be able to look at this seems to me all that is needed, because if we know how to look, then the whole thing becomes very clear, and to look needs no philosophy, no teacher. Nobody need tell you how to look. You just look» [Krishnamurti, 1969: p. 15].

In India philosophers are called «Darshanas». «Darshan means to look, not to think» [Osho, 1976]. So it means a look in which there is the astonishment in front of the Unity of the Universe, the unity of micro- and macrocosm, the unity of the inner and the outer. To look in order to wonder at the unity of life which is not intellectualized, schematized, or reduced to something else; it can be only seen to be astonished. We should look in order to wonder. But what is «the quality» of such a looking? - Contemplation. Modern philosophy has forgotten that its purpose is to attract a human being to the contemplation of the Unity of Universe.

\subsection{The Role of Contemplation in the Seeing of a Miracle}

The word «contemplation» (from Latin «contemplari» - «to gaze attentively, observe» - originally means «to mark out a space for observation», and derives from com- and templum, i. e. «area for the taking of auguries») nowadays is excluded from philosophical dictionaries, books and articles. Nobody writes about it because it is considered that contemplation refers to religion; that is why it is inappropriate to mention it in the company of academic philosophers. A contemporary philosopher should demonstrate his/her distance from religion; otherwise he/she will not be taken seriously. But the misfortune of the contemporary civilization is in the fact that contemplation is not practical at all; that it is considered as a rudiment of Ancient World and the Middle Ages.

In Ancient Greece contemplation was defined by the notion $\theta \varepsilon \omega \rho i \alpha$ (theoria), the meaning of which was in the looking at the Unity of Universe as the creation of God ( $\theta$ cíov - «divine things», that reflects the notion of «contemplation of the nature's divine organization», i.e. Cosmos). In the Middle Ages the notion «contemplation» meant the contemplation of God, of the Divine Essence, meanwhile as in Antiquity the spectacular in nature (plagues, volcanoes, rivers, floods, forests, mountains etc), dramatic healing, the intuitions of sages and artists, the visions of prophets, were considered as miraculous [see Parsons, 1969: p. 84]; the vision of the divine well-organized, structurized hierarchy of the Cosmos was considered as miraculous.

Let us consider Plato's notion of anamnesis. It is well-known that Plato recognized metempsychosis, i.e. a transition of a soul from one body to another. Such a transition is circular. Before the first embodiment a soul contemplated divine things, but after the embodiment it forgets about divine reality. So we as embodied entities need to cognize our own soul and to recollect the first, clear impressions about divine reality. A recollection reconnects an embodied soul with divine reality and such a re-connection is the cause of an embodied soul's astonishment. In other words such re-connection can be called religion (the word «religion» derives from Latin «religare» which means «reconnection with God, divine, transcendent reality etc.»). According to Plato, we move to the Supreme Good with the help of recollection, a contact with Ideas, which already exist in some static «past eternity». The Supreme Good becomes accessible for us in a soul's memory with the help of Socrates' maevtics [Mooney, 1998: p. 287]. Eternity means constant circulation of the same. As Plato puts: «For a man must have intelligence of universals, and be able to proceed from the many particulars of sense to one conception of reason; this is the recollection of those things which our soul once saw while following God-when regardless 
of that which we now call being she raised her head up towards the true being» [Phaedrus, 249bc].

Plato supposes that the most perfect is the human being which has recollected and activated the knowledge of divine reality, that is what he or she knew before embodiment. Plato speaks about plunging into the depths of soul, into subconscious memory which contains the necessary knowledge that can help a human being to become inspired and transcend everyday life.

Anamnesis returns a human being to the real, i.e. «the new» which was forgotten. Suddenly I recollect what I have forgotten and this recollection immediately causes the astonishment. The recollection leads us to an encounter with the new. Only the real is the new and vice versa. In recollection the old becomes the new. A soul has memory, but when a soul reincarnates it forgets all that it had seen before reincarnation. Some souls have stronger memory than others. The depth of forgetting depends on the soul's power to remember. Aristotle says that philosophy begins with astonishment. We can interpret this as following: a human being feels astonishment seeing the new and this new, the real, needs to be understood.

The contemporary author T. Merton writes: «We are living through the greatest crisis in the history of man; and this crisis is centered precisely in the country that has made a fetish out of action and has lost (or perhaps never had) the sense of contemplation» [Merton, 1980: p. 164]. This means that action without contemplation is false and destructive. We as active persons need some whole vision of life in order to act successfully. So, contemplation is «special dimension of inner discipline and experience, a certain integrity and fullness of person development, which are not compatible with purely external, alienated, busy-busy existence» [ibid., p. 157].

There is a prejudice that a contemplator is entirely passive, that he or she is in the state of separation from the lifeworld. So the question arises: what is the use of such contemplation? The answer is paradoxical: they contemplate in order to act better. Contemplation is active. Only alienated human being is passive, although he/she may appear active. The division between practice and theory leads to the disappearing of a miracle; when theory becomes the system of rational conclusions on the basis of empirical observations and experiments, it also leads to the disappearing of a miracle in the world.

\subsection{A Miracle as «the Saturated Phenomenon»}

Well-known theologist J.P. Manoussakis emphasizes that a transcendent can be perceived sensually, but in an unusual way [Manoussakis, 2007]. What does an unusual way mean? In order to answer this question we must consider the concept of «the saturated phenomenon» introduced by J.-L. Marion. Such phenomenon transforms usual intentionality into unusual or «inverse intentionality» (J.P.Manoussakis).

So, everything can be a miracle - a tree, the sky, a flower, grass, an insect, a dog, a cat, sea etc. - if they are perceived by a human being not as the intentional objects but as «the saturated phenomena». "The saturated phenomenon» is a phenomenon, which takes all the space. The perception of such phenomenon is accompanied by astonishment since it is a miracle that raises amazement. On the contrary, a poor phenomenon ${ }^{4}$ is the phenomenon which appears in our perception as an object. An object does not astonish, as it is, according to M. Heidegger, only an instrument which is used by a human being to reach

\footnotetext{
${ }^{4}$ J-L. Marion also names a poor phenomenon «a common-low phenomenon» [Marion, 2008: p. 41].
} 
his/her goals. An object, as a poor phenomenon, is reduced to me, to its needs; this means that an object exists for $\mathrm{me}^{5}$. I. Kant argues that there is no other perception than the perception of objects. Plato shows that the perception of objects is only a shadow of the real, of what is. "The saturated phenomenon» cannot be reduced to an object. It is given in perception as the whole and indivisible, that is why it astonishes: «Any phenomenon that produces amazement imposes itself upon the gaze in the very measure (or, more precisely, in the very lack of measure) that it does not result from any foreseeable summation of partial quantities. Indeed, it amazes because it arises without any common measure with the phenomena that precede it, without announcing it or explaining it - for, according to Spinoza, it "has no connection with the others"» [Marion, 2008: p. 35]. Thus, «the saturated phenomenon» cannot be foreseen, since intuition, which saturates it, does not allow to distinguish and sum up a finite number of finite parts, that is why it annuls any possibility of foreseen the phenomenon. «The saturated phenomenon» very often imposes, thanks to amazement, as it is not a mere summation of the parts that can be combined due to the transcendental synthesis of the homogeneous; it appears unexpectedly, as a perception of heterogeneous, which produces the experience of the absolute novelty [ibid., p. 36-38]. That is why, in the case of «the saturated phenomenon», intuition gives reality without any limitation. A poor phenomenon - object - depends on the gaze of I, on its intentionality. «The saturated phenomenon» is free from the gaze of I, i.e. observer; therefore it is beyond the limits of the intentional relation between me and object. In order to perceive «the saturated phenomenon» we need other intentional relation between subject and object, which can be named «inverse intentionality» [Manoussakis, 2007: p. 20-24].

The classical model of intentionality was introduced by F. Brentano and more developed by his pupil E. Husserl ${ }^{6}$ : intentionality is the feature of consciousness to be directed towards objects; such definition of intentionality makes it the bridge between consciousness and objects. Besides they considered that only consciousness, i.e. psychics, has intentionality, whereas physical objects do have not it. But I do not agree with their definition.

Why do I think that their definition of intentionality is false? F. Brentano and E. Husserl didn't consider the possibility that in the contemplative state intentionality undergoes inversion. This means that it does not go from I, i.e. subject, which immanently experiences object, but goes from what is contemplating. They didn't even suppose that

${ }^{5}$ I. Kant just speaks of the phenomenal world for us and noumenal world for itself. The "two-world" Kantian position - for us and itself - confirms that human perception is limited only to the perception of objects, i.e. poor phenomena. Speaking more precisely, I. Kant forbids a human being to come into the world of the things-in-themselves.

${ }^{6}$ Here is the F. Brentano's famous definition of intentionality: «Every mental phenomenon is characterized by what the Scholastics of the Middle Ages called the intentional (or mental) inexistence of an object, and what we might call, though not wholly unambiguously, reference to a content, direction toward an object, or immanent objectivity. Every mental phenomenon includes something as object within itself, although they do not all do so in the same way. In presentation something is presented, in judgment is something is affirmed or denied, in love loved, in hate hated, in desire desired and so on. This intentional in-existence is characteristic exclusively of mental phenomena. No physical phenomenon exhibits anything like it. We could, therefore, define mental phenomena by saying that they are those phenomena which contain an object intentionally within themselves » [Brentano, 1995: p. 68]. F. Brentano stressed that only mental phenomena are intentional. E. Husserl understood the intentionality more widely: «Under intentionality we understand the own peculiarity of mental processes "to be consciousness of something"» [Husserl, 1982: p. 200]. 
intentionality may go from objects, such as forests, rivers, oceans, animals, stones, glass, i.e. nature. In the contemplative state the things speak for themselves; so we don't construct any presentations or representations in order to cognize and to explain them. In such state the things themselves appeals directly to our consciousness. So usual intentionality can be transformed into «inverse intentionality» in the contemplative state, when we don't see an object (a poor phenomenon), but object becomes «the phenomenon», i.e. the thing that is talking to us, amaze us and therefore is a miracle. Thus, amazement needs a miracle as noesa needs noema, but in the inversed direction, i.e. noema («the saturated phenomenon») needs noesa (intuition in the state of contemplation, which accompanied by pure thinking, i.e. thinking without me). Intuitive, pure thinking can understand the language of «the saturated phenomenon», which appeals to us. Contemplative or religious consciousness is quiet, «non-intentional»; therefore it can understand the things-in-themselves.

Thus, astonishment is not produced by a human being itself, by me, but is born by the very miracle, i.e. «the saturated phenomenon». It is like the sun which rises from the horizon, from beyond the limits of a human being, elucidating the sphere of poor phenomena - intentional objects. Going through a miracle leads a human being beyond the limits of his/her subjectivity. In this context it is worth while mentioning D.J. Caputo's thought that human experience is real only when it overcomes the limits of possible and takes us into the sphere of the impossible [Caputo, 2001: p. 109]. Such a phenomenon of the impossible is «the saturated phenomenon», i.e. a miracle. That is how D.J. Caputo describes the impossible: «The impossible, I said, is what makes experience to be experience, makes it truly worthy of the name "experience", an occasion in which something really "happens", as opposed to the regular grooves and tick-tock time humdrum life, when nothing much is really going on» [ibid., p. 11]. The possible is connected with the future that can be foreseen; it is something that will come true in the near future. Whereas the impossible does not have the predictable future, thus, as Caputo says, it has «absolute future» that cannot be foreseen [ibid., p. 8]. "The absolute future» transfers us into something which does not exist in the meantime but is going to happen, i.e. a miracle. But for the present we just do not realize this possibility, the possibility of a miracle. In such a sense, a miracle is the possibility of the impossible in «the absolute future».

Reading the works of the authors mentioned above we can find thoughts similar to the thoughts of J. Krishnamurti. He maintains that experiencing of a miracle is not the subjective state of a human being, I, but a certain state, when simple things, which constantly surround him/her, become independent from the intentional gaze of I, and then a human being wonders and truly sees what can be called the thing itself of the each object/poor phenomenon: «...I see lovely cloud, or a mountain clear against the sky, or a leaf that has just come in springtime, or a deep valley full of loveliness and splendour, or a glorious sunset, or a beautiful face... I look at these with intense delight and as I observe them there is no observer but only sheer beauty like love. For a moment I am absent with all my problems, anxieties, miseries - there is only that marvellous thing» [J. Krishnamurti, 1969: p. 31].

So we can stress that these postmodern theological thinkers (J.-L. Marion, J.P.Manoussakis and D.J. Caputo) involved phenomenological method for rehabilitation of a miracle in everyday life and introduced non-traditional definition of a miracle. It includes the manifestations of the impossible, the new, the unseen etc. 


\section{Conclusion}

When we consider everyday life of a human being then we can see that it is mediated by habits, repetition, physical body, social determination, political and economical systems etc. A miracle is an encounter with the new which is not determined by any «criteria» and by any mediation mentioned above. That is why it astonishes. It is possible to feel astonishment only looking at the disclosed chain of the cause and effect relationships which determine the monotonous course of the daily life. But such an encounter with the new «is flitting and fragile. As soon as it is consolidated into a lasting and stable relationship, it is already an institution» [Ricoeur, 1965: p. 105]. An encounter with the new is a particular clearing if we may use Heidegger's term Lichtung. But «sphere of objectivation» (A. Heller) gradually absorbs this clearing. Such absorption eliminates a miracle, the new, from everyday life.

In this article we tried to show the connection between a miracle, contemplation and novelty in order to clear up their meaning for the formation of religious experience. This clearing up is obtained by means of combination of the phenomenological approach and the etymological analysis of the concept of a miracle. Such a combination of the approaches to the study of a miracle helps to define a miracle more precisely in the context of the history of philosophy.

In our opinion a miracle is neither violation of laws of nature, nor intervention of God (Deity), some «supernatural forces». A miracle is present in everything that surrounds us, in everything that we can perceive. Someone may say that if everything is a miracle then nothing is a miracle. This is a false sentence. Our ancestors (as well as every human being in its childhood) perceived everything that was around them as a miracle. It can be traced through the etymological study, for what is now just «to look at» originally meant «to look with wonder, to marvel» (for example, in Ukrainian and Spanish languages). But we gradually get accustomed to our surrounding and our perception becomes rigid, insensitive. In order to see the miraculous in the ordinary, in the habitual we should learn the art of contemplation, i.e. to look at the things in a new way, what means to see not the things themselves, as Husserl thought, but the divine reality beyond them. Therefore, through the contemplation our connection with the divine is renewed and religious experience becomes the part of our everyday life.

\section{BIBLIOGRAPHY}

Етимологічний словник української мови: в 7 т.; т. 2 / Укл.: Н. С. Родзевич та ін. - К.: Наукова думка, 1985. - 572 с. (Etymological Dictionary of the Ukrainian Language in Seven Volumes: Vol. 2 / Lexicographers: N.S.Rodzevych and others [in Ukrainian]. Kyjiv: Naukova dumka, 1985. -572 p.)

Сошинский C. А. Чудо в системе Вселенной // Вопросы философии. - 2001. - №9. - С. 8297. (Soshynskyj S.A. A Miracle in the System of the Universe [in Russian] // Voprosy Filosofii. - 2001. - №9. - P. 82-97.)

Хмель Т. В. Чудо как форма восприятия мира // Сучасне світорозуміння: духовні аспекти розвитку науки в XXI столітті. Матеріали науково-практичної конференції. - Дніпропетровськ: Національний гірничий університет, 2010. - С. 41-43. (Khmel' T.V. A Miracle as a Form of Perception of the World [in Russian] // Contemporary Understanding of the World: the Spiritual Aspects of the Scientific Development in the XXI century. The Proceedings of Scientific and Practical Conference. - Dnipropetrovs'k: National Mining University, 2010. - P. 41-43.) 
Brentano F. Psychology from an Empirical Standpoint / transl. by Antos C. Rancurello, D. B. Terrell and Linda L. McAlister. - London-N.Y.: Routlege, 1995. - 322 p.

Bunge M. Causality. The Place of the Causal Principle in Modern Science. - Cambridge: Harvard UP, 1959. $-380 \mathrm{p}$.

Caputo D.J. On the Religion. - N.Y.-London: Routlege, 2001. - 147 p.

Corner D. The Philosophy of Miracles. - N.Y.-London, 2007. -162 p.

Drange T. M. Science and Miracles (23.04.2013) // Electronic resource. Access mode: http://www.infidels.org/library/modern/ theodore drange/miracles.html

Encyclopædia Britannica: A New Survey of Universal Knowledge / The University of Chicago a.o. - Chicago; London; Toronto: Encyclopaedia Britannica, Inc.: William Benton, Publisher, 1959. - Vol. 15: Maryborough to Mushet Steel. - 997 p.

Hume D. Enquiries Concerning Human Understanding and Concerning the Principles of Morals / ed. by L.A. Selby-Bigge, $3^{\text {rd }}$ edition, revised by P. H. Nidditch. - Oxford: Clarendon Press, 1975. $-417 \mathrm{p}$.

Husserl E. Ideas. First book / transl. by F. Kersten. - Dordrecht; Boston: Kluwer Academic Publisher, 1982. - xxiii, $410 \mathrm{p}$

Krishnamurti J. The Freedom from the Known. - N.Y.: Harper \& Row, 1969. -124 p.

Lewis C. S. Miracles: a preliminary study. - N.Y.: Macmillan Co., 1947. - 220 p.

Manoussakis J.P. God after Metaphysics. A Theological Aesthetic. - Bloomington: Indiana UP, 2007. - xiii, $213 \mathrm{p}$.

Marion J.-L. The Visible and the Revealed / transl. by Christina M. Gschwandtner. - N.Y.: Fordham UP, 2008. - 180 p.

Mikolejko Z. What is a Miracle? Is there a Miracle? (20.04.2013) // Electronic resource. Access mode:

http://www.polradio.pl/5/116/Artykul/72451,\%D0\%A7\%D0\%B8\%D0\%BC\%D1\%94\%D0 $\% \mathrm{~B} 4 \% \mathrm{D} 0 \% \mathrm{~B} 8 \% \mathrm{D} 0 \% \mathrm{~B} 2 \% \mathrm{D} 0 \% \mathrm{BE}-\% \mathrm{D} 0 \% \mathrm{~A} 7 \% \mathrm{D} 0 \% \mathrm{~B} 8-\% \mathrm{D} 1 \% 94$ $\% \mathrm{D} 0 \% \mathrm{~B} 4 \% \mathrm{D} 0 \% \mathrm{~B} 8 \% \mathrm{D} 0 \% \mathrm{~B} 2 \% \mathrm{D} 0 \% \mathrm{BE}$

Merton T. Contemplation in a World of Action. - London: Unwin Paperbacks, 1980. - xxviii, $384 \mathrm{p}$.

Mooney Edward F. Repetition: Getting the world back // The Cambridge Companion to Kierkegaard / Ed. by A. Hannay and Gordon D. Мarinoю - Cambridge: Cambridge UP, 1998. P. 282-307.

Moore T. The Re-enchantment of Everyday Life. - N.Y.: HarperCollins Publishers, 1996. - xx, $396 \mathrm{p}$.

Nickell J. Examining Miracle Claims (20.04.2013). // Electronic resource. Access mode: http://www.infides.org/ library/modern/joe_nickell/ miracles.html

Osho The Mustard Seed: My Most Loved Gospel on Jesus (30.10.2013) // Electronic resource. Access mode: http://oshosearch.net/Convert/Articles_Osho/

The_Mustard_Seed_My_Most_Loved_Gospel_on_Jesus/Osho-The-Mustard-Seed-MyMost-Loved-Gospel-on-Jesus-index.html

Parsons Howard L. A Philosophy of Wonder // Philosophy and Phenomenological Research. Vol. 30. - № 1 - Sept., 1969. - P. 84-101.

Ricoeur P. History and Truth. - Evanston: Northwestern University Press, 1965. - xxiv, 333 p.

Swinburne R. The Concept of Miracle. - London: Macmillan; N.Y.: St Martin's Press, 1970. - ix, $76 \mathrm{p}$. 


\section{Ihor Karivets'}

\section{Contemplation, Miracle and Novelty: Towards the Foundations of Religious Experience}

In this article, on the basis of analysis of the classical definition of a miracle (from D. Hume to C. S. Lewis and R. Swinburne) and the nonclassical one (J.L.Marion and J.P. Manussakis), the phenomenological and the etymological aspects of a miracle are examined. Taking into consideration the historical development of the concept of a miracle, the author proves the connections between contemplation, miracle and novelty. They are necessary for the constituting of religious experience. Faith itself, in theological sense, is not determinative for religious experience. It has sense only when it is integrated into contemplation. True religious experience discloses the chain of routine, repetitive everydayness and lets a human being to see the new in the usual. The religious experience is based on the art of contemplation which helps a human being to look with astonishment. The author argues that phenomenological approach to a miracle combined with the etymological analysis is a valuable method for the study of a miracle in the context of the history of philosophy.

Ihor Karivets', PhD in Philosophy, Associate Professor at the Chair of Philosophy, Lviv National Polytechnic University

Ігор Карівець, кандидат філософських наук, доцент кафедри філософії Національного університету «Львівська політехніка»

Игорь Каривец, кандидат философских наук, доцент кафедры философии Национального университета «Львовская политехника» 